\title{
Success' Conditions of Microfinance to Fostering Sustainable Development
}

\author{
Mongi Lassoued ${ }^{1}$ \\ ${ }^{1}$ Department of Economics, Higher Institute of Finance and Fiscality, University of Sousse, Sousse, Tunisia \\ Correspondence: Mongi Lassoued, Department of Economics, Higher Institute of Finance and Fiscality, \\ University of Sousse, Street of 18 January 1952, P.O. Box 4000, Sousse, Tunisia. Tel: 216-2825-5183. E-mail: \\ lassouedmongi4@gmail.com
}

Received: November 14, 2020

Accepted: November 20, 2020

Online Published: December 5, 2020

doi:10.5539/ijef.v13n1p22

URL: https://doi.org/10.5539/ijef.v13n1p22

\begin{abstract}
With a loan portfolio estimated at $\$ 124.1$ billion in 2018, 139.9 million borrowers benefited from microfinance services, compared to just 98 million in 2009 (World Bank Group, 2018). Despite a low quality portfolio and high borrowers' costs, the portfolio in the Middle East and North Africa (MENA) shows a remarkable increase of $20 \%$ but with a decrease of 6.6 points (Microfinance Barometer, 2019). Most of empirical studies have focused on the issue of microfinance, and research conducted on the effectiveness of microcredit is surprisingly scarce or even non-existent in the MENA region. In addition, microcredit could lead to sustainable development in the region via an income effect. The main objective of this paper is to determine the impact of microcredit on sustainable development for 10 selected MENA countries over the period 1990-2018. Empirical results paradoxically show a negative effect of microcredit on sustainable development. Although, the limitations of data, the present paper also contributes to the existing literature by advising conditions for the success of microcredit aiming for a better promotion of sustainable development.
\end{abstract}

Keywords: microfinance, sustainable development, MENA countries

\section{Introduction}

The main objective of microfinance is to financially empower the poorest people and stimulate sustainable development (García-Pérez et al., 2018). Sustainable development is a multidimensional concept comprising social and economic prosperity without contravening the needs of future generations. The socio-economic development depends on a commitment to the well-being of generations in the future. Sustainability has been translated into a balance between social, financial, environmental and governance dimensions, indicating the importance of the interrelation between these dimensions in short and long term. The primary goal of sustainable development is to meet current needs without harming the needs of future generations. Researchers and practitioners have approached the subject of sustainable development from different angles, taking into consideration the achievement of sustainable development as an important challenge. It is mainly due to the complexity and diversification of the factors involved. At the micro level, sustainable development is ensured by organizational sustainability which takes into account short and long term financial, environmental, and social and governance performance. By addressing the multidimensional aspect of poverty and sustainable development, financial exclusion is more prevalent mainly in sub-Saharan Africa, while educational deprivation is remarkable in the Middle East and North Africa (MENA) region which suffers from a high lack of basic infrastructure (World Bank, 2018). Therefore, microfinance should reduce the poverty rate and promote sustainable development (Convergences Barometers, Microfinance Barometer, 2018).

The Microfinance sector is growing, the number of microcredit institutions in 2018, reached 916 institutions serving almost 140 million borrowers globally (Microfinance Barometer, 2019). This number was only in the order of 98 million borrowers in 2009 of which $80 \%$ are women and $65 \%$ of these borrowers live in rural areas (Convergences Barometers, Microfinance Barometer, 2018). With a credit portfolio estimated at $\$ 124.1$ billion, microfinance institutions (MFIs) recorded a new year of growth in 2018 (+ 8.5\% compared to 2017). South Asia has the highest number of borrowers in the world (85.6 million in 2018). The notable specificity of the South Asian region is that, in the year 2018, $89 \%$ of borrowers are generally women. Latin America and the Caribbean region alone hold $44 \%$ of the total microcredit sector portfolio, with $\$ 48.3$ billion in outstanding loans $(+5 \%)$ per 
year on average since 2012 (Microfinance Barometer, 2019). This region is still characterized by a low rate of penetration of MFIs that deals the least with rural populations, who constitute only $23 \%$ of their clients (OECD, 2019). The countries of Eastern Europe and Central Asia constitute smaller microfinance markets. The number of borrowers in this region has only increased by 30\% since 2012, reaching 2.5 million in 2018 (Microfinance Barometer, 2019).

The economies of the MENA are diverse. Some countries in the region are rich in oil which makes the poverty rate among the lowest in the world. About 5\% of the region's population lives on $\$ 1.25$ per day and about $17 \%$ live on a poverty line of $\$ 2$ per day in 2005. Data from the World Bank (World Bank, 2019) indicates that around $15 \%$ of Yemenis, $10 \%$ of Moroccans and $17 \%$ of Egyptians have a lower consumption rate of less than 5\% per day. Economic growth in the MENA region is expected to improve modestly to an average of $2.6 \%$ (1.4\% on average in 2017). The MENA region today has one of the highest youth rates of unemployment in the world (24\%) and it is much higher among women (Women in Global Health, 2020). Job creation is crucial in the MENA, which will need 300 million additional jobs by 2050 (OECD, 2020). This could also promote female entrepreneurship where the female activity rate $(26 \%)$ is significantly lower than that recorded in comparable countries (IMF, 2019). In this regard, the empowerment of the poor and the fight against poverty in the MENA region should be a primary strategy. The credit portfolios of countries in this region have also increased during this period. The MENA region experienced only low growth between 2017 and $2018(+1 \%)$. The return on assets remains positive (1.9\%) but below (-1.4 points) (Microfinance Barometer, 2019).

Reviewing the existing literature on microfinance, we can retain that microfinance in the MENA region has not been studied from the point of view of sustainability. Almost no empirical research has addressed the issue of the impact of microcredit on sustainable and sustained development in the MENA region by taking into account regional specificities. For this reason, the aim of this study is to explore to what extent microcredit institutions stimulate sustainable and sustained development especially in the MENA region. Our main objective here is to determine the conditions for the success of microcredit programs to stimulate sustainable development in the MENA region.

The rest of the paper is organized as follows. Section 2 draws an overview of the literature on the linkage between microfinance and sustainable development. Section 3 outlines the different conditions leading to the contribution of microcredit programs to the objectives of sustainable and sustained development. Section 4 describes the data and the econometric framework. Section 5 interprets the results. Section 6 concludes.

\section{Literature Review}

Since the early 1980s, microfinance has enabled households and businesses, especially small ones that have not benefited from formal funding, to access several financial services such as microcredit, micro-savings, micro-insurance and net money transfers. It aims at serving the poorest populations (Widiarto et al., 2017). Most of the exiting studies focused on microfinance have looked for the socio-economic performance of microfinance institutions (García-Pérez et al., 2017). However, the performance of microcredit institutions has hardly been explored through a holistic approach that takes into account integrative sustainability (Morduch, 1999). On the other hand, the MIX Market Financial Performance Report 2017 shows that the effectiveness of microfinance programs depends on certain regional specificities that could influence the expected results (Khamar, 2020). Several other studies indicate that these regional specificities must be taken into account when studying the effectiveness of microcredit (Archer \& Jones-Christensen, 2011). Most of the empirical work focused on certain main aspects that characterize microfinance institutions such as their financial structure, the important role played by foreign donors (García-Pérez et al., 2018), the heterogeneity of microfinance institutions (MFIs), legal status and its location and the mechanisms adopted by the institutions to control the specific risks incurred (Morduch, 1999).

Some researchers have approached the subject of microfinance relying on the Hofstede model, integrating social, environmental, and financial and governance principles (Khamar, 2020). Taking into account the individualist-collectivist dimension, research on microfinance shows a positive impact on these societies which are more collectivist and where there is more confidence (Atmadja et al., 2016). The action to avoid uncertainty through regulations and laws to reduce ambiguity and insecurity in microfinance becomes imperative. The literature on microfinance has shown a reduction in the interest rates applied to loans in countries which follow strict regulations or laws (García-Pérez et al., 2017). Some other research has shown that scaling up microfinance programs helps mitigate the credit risk of institutions offering microloans under adverse economic conditions (Morduch, 1999). The cultural dimension of masculinity-femininity is also relevant and has been analyzed in order to establish the relationship between microfinance and gender inequality (Zhang \& Posso, 
2017). According to studies carried out by the United Nations Development Programs (UNDP) (Note 1) and the World Bank (Note 2), microfinance is seen as extremely crucial for empowering women. This sector could encourage women to improve their decision-making and involve them in order to improve their standard of living through financial autonomy (Roodman \& Qureshi, 2008). Poverty rates have also been found to be higher in countries where there is gender discrimination. However, Daley-Harris (2009) found that microfinance is not the only solution to lift women out of the circle of poverty. According to García-Pérez et al. (2018) managerial capacities and women's involvement are other factors that can accompany microcredit programs to contribute to economic and sustained development.

Several studies related to microfinance have been carried out by taking into consideration social, financial, environmental and governance principles. In addition, social and financial analysis was predominant in the existing literature (García-Pérez et al., 2017). Most of the studies focused on the relationship between microfinance and the socio-economic environment (Warnecke, 2015). Socio-economic factors have been considered as a main component that links the financial performance and governance of microcredit institutions (Archer \& Jones-Christensen, 2011). This makes it possible to analyze the regulatory changes and the conditions required to implement successful microfinance stimulating sustainable development (Ramaswamy \& Krishnamoorthy, 2016). However, until today, most of research studies that have analyzed the performance of microfinance institutions with a holistic and sustainable approach are surprisingly rare or even almost absent (García-Pérez et al., 2018). In addition, the results on the effectiveness of microcredit programs do not lead to a consensus on the effects of microfinance on financial inclusion, poverty and therefore on improving the living conditions of households or equity between male and female borrowers (Morduch, 1999). The studies on microfinance are more developed in the South Asian region, however in other regions such as the MENA are rarely carried out. Each of the regions has its own characteristics (Kar, 2017). In this regard, the cultural and organizational dimensions require studying microfinance institutions (MFIs) according to a sustainability approach taking into account regional specificities. To do so, this study seeks to examine the extent to which microfinance institutions (MFIs) contribute to sustainable development in the MENA region.

\section{The Conditions for a Microcredit's' Contribution to Sustainable Development}

Microcredit was considered to be an effective tool to fight against poverty through income effects and drainages of resources for poor households. However, some researchers have raised uncertainties and doubts that could call into question the alleged effectiveness of microcredit programs. Bateman (2012) synthesized a critique of microcredit programs in his work entitled "Why doesn't microfinance work? The Destructive Rise of Local Neoliberalism" (Bateman, 2012). Several other works such as Servet (2007) had previously questioned the widespread illusions about the supposed effectiveness and capacity of microcredit programs. Balkenhol (2009) has shown that the success of microcredit should be achieved with direct or indirect grants to the institutions that grant the loans. It is often rare for this success of the microloans to be reproduced in a sustainable way because these programs encounter several difficulties. Some studies have shown that a positive impact of microcredit cannot depend only on the good management of institutions and proper regulation of the microcredit sector. Our contribution is to identify the conditions necessary for microcredit to have a direct and rapid expected impact on sustainable development. These conditions are far from being ethical or moral standards for the functioning of microcredit institutions. They are treated here from a socioeconomic (Note 3) point of view at three levels: microeconomic, mesoeconomic and macroeconomic.

In order for microcredit to have an income effect, the clients benefiting from these microloan services must belong to a so-called "poor" population. However, in reality there are strong doubts that the poor were the actual target of these microcredit loans. It has been found that there is very limited financial inclusion in most developing countries which leads to increased demand for microcredit by non-poor populations (Demirgüç-Kunt \& Klapper, 2012a). Some studies carried out by the World Bank have shown that a large part of the population is located above the poverty line and thus finds itself in a situation of financial exclusion. It has also been observed that poor populations who experienced financial exclusion must, a priori, present greater reimbursement guarantees. Some other works have shown that microcredit institutions are much more established in urban rather than rural regions and that very few of these institutions have updated poverty databases (Beck et al., 2011). Servet (2007) shows that when microcredit is in fact granted to the non-poor, this contributes to increasing inequalities in income and in the distribution of wealth. This requires a good knowledge of the socioeconomic characteristics of the target populations of microcredit in order to act positively on the economy.

The funds collected from microcredit should be used effectively in projects allowing increasing productive capacities through the development of micro-entrepreneurship. Julie-Gifford's survey in Kampala shows that micro loans should be extended even more to men because he found that male activities are much more 
profitable than female ones (Gifford, 2004). However, Zelizer (2005) demonstrates that it is difficult to control the final use of the micro loans granted. Bateman (2012) asserts that only a small fraction of microloans are intended to increase productive projects. Some other studies have shown that most microcredit is intended for final consumption (food, schooling, funerals and medical expenses). The Measuring Financing Inclusion Report developed by Demirgüç-Kunt and Klapper (2012a) states that in Kenya microcredit is mainly used to pay family expenses and they are less intended for income-generating activities. The micro loan could have a directly positive effect on income if the investment is made in an activity for which there are opportunities. However in reality, this is rarely seen in most developing countries (Bateman, 2012; Servet, 2007). We see the predominance of entrepreneurial mimicry behavior which considerably reduces the potential effectiveness of these micro loans. This is due to local competition between the same investment activities. When these practices are not taken into account, the income effect of microloans ultimately turns out to be vastly overestimated.

The costs of the micro loan, through the interest rate and commissions paid, should be lower than the return rate of the investment activity (Beck et al., 2011). These additional costs are more pronounced for microcredit institutions than for commercial banks. Some studies have shown that holding a bank account, in some developing countries, costs the equivalent of a quarter of gross national product (GNP) per capita, which explains the great reluctance to have a bank account by a large number of borrowers (Demirgüç-Kunt $\&$ Klapper, 2012b). In the same context, Beck et al. (2011) found that almost $80 \%$ of microloans in the world are granted with interest paid higher than the returns of the financed activities. Let us quote the example of agricultural activities which do not add more than $15 \%$ (max). Besides, these micro loans do not even allow financing the totality of the activity such as the purchases of seeds and fertilizers. This situation induces under-remuneration of the labor force and the owners; which results in a draining of resources from the agricultural world towards the microcredit institutions. The amount and quality of micro credits are not enough to support micro-entrepreneurship. Other complementary factors are essential for the micro loan to be beneficial, such as technical, financial and managerial training for the beneficiaries of these small funds. Borrowers must have the capacity to be better informed, upstream about supplies and downstream about potential customers.

Some studies carried out on poverty have shown that low incomes lead to a low endowment of resources to face risks. This situation prevents the poorest populations from preventing risks (Gifford, 2004). Death rates are higher due to the high prevalence of the virus in some developing countries. This depresses the repayment rates on micro loans and could have a negative impact on the level of confidence. In addition, the possibility of recourse to insurance is extremely reduced which pushes borrowers to switch to the less risky investment activities that generate the lowest income. Hence it is necessary to combine microcredit with insurance and to secure savings, a task that is not easy in these countries. Microcredit could also have an overall positive impact on income when dividends paid and interest paid by borrowers does not drain resources for the sole benefit of foreign shareholders. These dividends or profits should satisfy a local financing need (Beck et al., 2011; Servet, 2007). This is mainly due to the existence of foreign financial groups that are shareholders in microcredit institutions in most developing countries. However, the existence of cooperative or mutuality institutions reduces the outflow or flight of capital thanks to this domestic mobilization of savings.

\section{Data and Methodological Framework}

\subsection{Data}

The dataset used in this study spans the period from 1990 to 2018, comprises 10 MENA countries, namely Egypt, Iraq, Jordan, Lebanon, Morocco, Palestine, Sudan, Syria, Tunisia, Yemen. The World Bank World Development Indicators (WDI) and the International Monetary Fund (IMF) databases have been used to collect the statistical data.

\subsubsection{Dependent Variable}

The dependent variable is the sustainable development. This variable is approximated by the net adjustment of the sustained development (GS) and computed by the World Bank as follows:

$$
G S=\left(G N I-C_{p}-C G+N C T\right)-\alpha K_{p}+\beta K_{h}-\delta K_{n}
$$

Where GS represents the supported sustainable development variable; GNI is the gross national income; $\mathrm{C}_{\mathrm{p}}$ is the fixed capital consumption of poor households; CG corresponds to consumption for the public sector; NCT is the net current transfer; $\mathrm{K}_{\mathrm{p}}$ represents the produced capital which consists mainly of fixed assets; $\mathrm{K}_{\mathrm{h}}$ represents the investments in human capital; $\mathrm{K}_{\mathrm{n}}$ is to the depreciation of material capital.

\subsubsection{Independent Variables}

Our main independent variables are the active borrowers $(\mathrm{AB})$ approximated by the number of people benefiting 
from microcredit services; gross loan portfolio (GLP) which presents the gross portfolios of microcredit loans; Gini index (GINI) as a proxy to measuring income inequality; current health expenditure (CHE) measured by the percentage of public expenditure; human development index (HDI); mobility subscription (MS) determined by the use of telecommunication services. It includes the sum of mobile phone subscriptions, post-paid and prepaid; final consumption expenditure (FCE) measured by the addition of the consumption expenditure of private households and public sectors; inflation (INF), we use the GDP deflator to determine the increase in the general price level. This deflator is calculated as nominal GDP to real GDP ratio. Summary statistics for the dependent and independent variables are given in Table 1.

Table 1. Descriptive statistics

\begin{tabular}{|c|c|c|c|c|c|c|c|}
\hline & Obs. & Mean & Std. Dev. & Skewness & Kurtosis & Jarque-Bera & $\mathrm{P}$-value \\
\hline $\ln \mathrm{AB}$ & 290 & 3.944014 & 2.737413 & 0.459644 & 2.560535 & 12.54516 & 0.001887 \\
\hline $\operatorname{lnGLP}$ & 290 & 9.751749 & 3.183121 & -0.338097 & 3.354965 & 7.047474 & 0.029489 \\
\hline $\operatorname{lnCHE}$ & 290 & 1.713872 & 0.480802 & 0.992011 & 4.671491 & 81.32355 & 0.000000 \\
\hline $\operatorname{lnGINI}$ & 290 & 3.511900 & 0.334493 & -4.983915 & 26.25943 & 7737.668 & 0.000000 \\
\hline $\operatorname{lnMS}$ & 290 & 13.84688 & 3.245396 & -0.644768 & 1.908577 & 34.48714 & 0.000000 \\
\hline $\operatorname{lnHFIC}$ & 290 & 23.17940 & 0.828862 & 0.000641 & 1.376458 & 31.85035 & 0.000000 \\
\hline $\operatorname{lnGS}$ & 290 & 0.743538 & 0.227843 & -0.212000 & 1.535145 & 28.10071 & 0.000001 \\
\hline $\operatorname{lnIDH}$ & 290 & -0.791167 & 0.226964 & 0.102592 & 2.540603 & 3.058844 & 0.216661 \\
\hline $\operatorname{lnINF}$ & 290 & 1.811075 & 1.332504 & 0.209377 & 3.316174 & 3.326787 & 0.189495 \\
\hline
\end{tabular}

Note. All variables are in logarithm.

Source: Author's calculations based on data from WDI and IFM.

Table 2 presents the correlation matrix between the dependent and independent variables. The results indicate that GS negatively influences the different indicators except for the number of active borrowers $(A B)$ variable. The results show the existence of multicollinearity between the number of active borrowers $(A B)$ and gross loan portfolio (GLP), and between final consumption expenditure (FCE) and users of telecommunication services (MS).

Table 2. Correlation matrix

\begin{tabular}{|c|c|c|c|c|c|c|c|c|c|}
\hline & $\ln \mathrm{AB}$ & $\operatorname{lnGLP}$ & $\operatorname{lnCHE}$ & $\operatorname{lnGINI}$ & $\operatorname{lnMS}$ & $\operatorname{lnHFIC}$ & $\operatorname{lnGS}$ & $\operatorname{lnIDH}$ & $\operatorname{lnINF}$ \\
\hline $\ln \mathrm{AB}$ & 1.0000 & & & & & & & & \\
\hline $\operatorname{lnGLP}$ & 0.7278 & 1.0000 & & & & & & & \\
\hline $\operatorname{lnCHE}$ & 0.1250 & -0.340 & 1.0000 & & & & & & \\
\hline $\operatorname{lnGINI}$ & -0.0507 & -0.026 & 0.0620 & 1.0000 & & & & & \\
\hline $\operatorname{lnMS}$ & -0.1419 & -0.131 & 0.0347 & -0.085 & 1.0000 & & & & \\
\hline InHFIC & -0.1616 & -0.099 & 0.0386 & -0.131 & 0.7696 & 1.0000 & & & \\
\hline $\operatorname{lnGS}$ & 0.0288 & -0.068 & -0.060 & -0.312 & -0.421 & -0.353 & 1.0000 & & \\
\hline $\operatorname{lnIDH}$ & -0.1345 & -0.177 & 0.0001 & -0.394 & 0.5236 & 0.6834 & 0.2474 & 1.0000 & \\
\hline $\operatorname{lnINF}$ & 0.0293 & -0.037 & -0.138 & 0.1285 & 0.0260 & 0.0610 & -0.093 & -0.033 & 1.0000 \\
\hline
\end{tabular}

Source: Author's calculations.

\subsection{Quantitative Techniques}

To examine the impact of microfinance on the sustainable development in 10 selected MENA countries over the period 1990-2018, we estimate the following nonlinear regression model similar to that of Heckman and Burton (2017).

$$
G S_{i t}=A_{i}(A B)_{i t}^{\alpha_{i}}(G L P)_{i t}^{\beta_{i}}(C H E)_{i t}^{\chi_{i}}(G I N I)_{i t}^{\phi_{i}}(I D H)_{i t}^{\phi_{i}}(M S)_{i t}^{\gamma_{i}}(H F C E)_{i t}^{\theta_{i}}(I N F)_{i t}^{\alpha_{i}} \exp \left(\varepsilon_{i t}\right)
$$

This model requires in a first step to verify the homogeneous or heterogeneous specification of the data generating process. Econometrically, these amounts, testing the equality of the coefficients of our theoretical model, are studied at the individual level. Economically, the specification tests consist in determining whether we can assume that the sustained development is perfectly identical for these countries, or on the contrary, there are specificities to each one. The benchmark model can be written in the following log-linear form: 


$$
\begin{aligned}
& \ln (G S)_{i t}=\ln \left(A_{i}\right)+\alpha_{i} \ln (A B)_{i t}+\beta_{i} \ln (G L P)_{i t}+\chi_{i} \ln (C H E)_{i t}+\phi_{i} \ln (G I N I)_{i t}+ \\
& \varphi_{i} \ln (I D H)_{i t}+\gamma_{i} \ln (M S)_{i t}+\theta_{i} \ln (H F C E)_{i t}+\lambda_{i} \ln (I N F)_{i t}+\varepsilon_{i t}
\end{aligned}
$$

The errors $\varepsilon_{i t}$ are assumed to be identical, independent and of probability density following the normal distribution. Thus, we can assume that the constants $\ln \left(A_{t}\right)$ of our model may vary according to the individual dimension (Note 4) but that they are constant over time. This model has several possible configurations (Hurlin $\&$ Mignon, 2006). Table 3 represents the homogeneity test of the coefficients and constants that appear in the model of sustainable development supported for the sake of the 10 selected MENA countries.

Table 3. Test for homogeneity: Sustained development

\begin{tabular}{lccc}
\hline & Homogeneity of constants & Homogeneity of coefficients \\
\hline $\operatorname{lnGS}_{\text {it }}$ & $60.25(0.000)$ & $0.25(0.9016)$ \\
\hline
\end{tabular}

Note. F-statistics and associated p-values are in parentheses.

Source: Author's calculations.

Table 3 shows that all the coefficients of the static relationship which describes sustainable development as a function of the microcredit and the set of macroeconomic variables are identical for the 10 MENA countries despite the invariant effects being heterogeneous between those countries. Therefore, our benchmark model could be specified in the panel form with individual fixed or random effects.

\section{Empirical Results}

\subsection{Static Estimate of the Sustainable Development}

According to the F-test presented in Table 3, our specification model can be formalized by a panel with individual effects. In order to estimate the static relationship between the sustainable development and its determinants, we use appropriate techniques such as "Within" and Generalized Least Squares (GLS). The results of the estimates are shown in Table 4. The Within and GLS estimates shows a negative and insignificant elasticity for the sustainable development (GS) and the portfolio of microcredit loans (GLP). This elasticity is very low, which means that this development is weakly sensitive to the effects of microcredit. The results also reveal a negative and insignificant elasticity between sustainable development (GS) and current health expenditure (CHE). Hence, the contribution of these expenditures remains negligible in the attainment of a sustainable development rate for MENA countries during our study period. Thus, the income inequality which is approximated by the GINI index has an inverse effect on the sustainable development. The elasticity of sustainable development regarding GINI index has a negative and statistically significant sign. The telecommunication use services (MS) have a negative and significant impact on sustainable development (GS); however, this impact still remains considerably lower. Final consumption expenditure (FCE) plays a negative and significant role in the attractiveness of a sustainable development rate (GS).

\begin{tabular}{|c|c|c|c|c|}
\hline \multirow[b]{2}{*}{ Variables } & \multicolumn{2}{|c|}{ Within } & \multicolumn{2}{|c|}{ GLS } \\
\hline & Coefficients & P-value & Coefficients & P-value \\
\hline LAB & -0.000714 & 0.910 & 0.0019825 & 0.665 \\
\hline LGLP & -0.0080201 & 0.156 & -0.0050839 & 0.231 \\
\hline LCHE & -0.038883 & 0.120 & -0.0244341 & 0.201 \\
\hline LGINI & -0.0756472 & 0.009 & -0.0687861 & 0.013 \\
\hline LMS & -0.0260936 & 0.000 & -0.0256189 & 0.000 \\
\hline LHFIC & -0.1791519 & 0.000 & -0.1816068 & 0.000 \\
\hline LIDH & 0.8251504 & 0.000 & 0.8436773 & 0.000 \\
\hline LINF & -0.0038215 & 0.652 & -0.0022282 & 0.727 \\
\hline
\end{tabular}

Table 4. Estimation of static sustainable development relationship: Within and GLS regressions

Source: Author's calculations.

Furthermore, the human development indicator (HDI) ensures the increase in sustainable development since the elasticity of this indicator takes on a positive and significant sign. Inflation (INF) has an insignificant effect on sustainable development. The elasticity of the number of people who used microcredit (BA) services with respect to sustainable development shows contradictory signs between the two estimation procedures Within and GLS. 
This elasticity, estimated by Within, shows a negative and insignificant sign, while it has a positive and insignificant impact when estimated by GLS.

However, in order to ascertain the steadiness of this research's estimates, the Hausman test (Hausman, 1978) was performed to determine if it is and individual fixed effects or random effects. Since, Hausman's statistic $($ Chi-square $=2.09 ;$ Prob. $=0.9783)$ shows that sustainable development can be modeled by a panel with individual random effects. For this, the GLS is retained as a good method for estimating the sustainable development (GS). The results reported in Table 5, using GLS, show that all the microcredit and macroeconomic variables have negative impacts on sustainable development (SG) except the human development indicator (HDI) and the number of people who have used microcredit services (AB). However, it shows that the individual random effects are different depending on the country and we can see that the average effects of the omitted variables have a positive impact in: Tunisia, Egypt, Jordan, Sudan and Palestine. In contrast, the averages of the hidden variables are negative for the following countries: Syria, Yemen, Iraq, Lebanon and Morocco. In general, the average effects of the omitted variables are very small; this is an indicator of a good specification of our estimated model. Figures 1 depicts the individual random effects for the 10 selected MENA countries.

Table 5. Individual random effects: GLS regression

\begin{tabular}{lc}
\hline & Individual random effects \\
\hline Egypt & 0.004962 \\
Iraq & -0.027798 \\
Jordan & 0.011543 \\
Lebanon & -0.000473 \\
Morocco & -0.007901 \\
Palestine & 0.000913 \\
Sudan & 0.046525 \\
Syria & -0.015156 \\
Tunisia & 0.003705 \\
Yemen & -0.016320 \\
\hline
\end{tabular}

Source: Author's calculations.

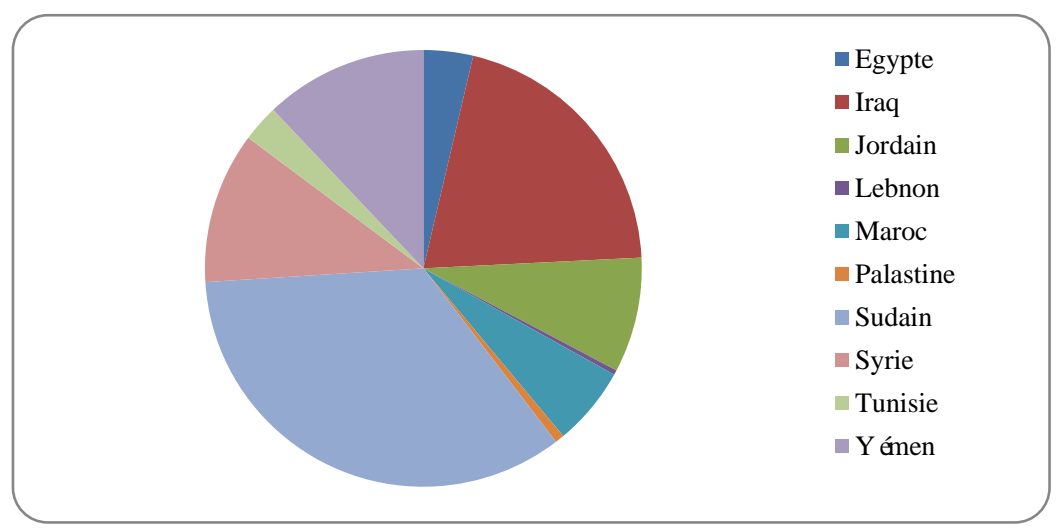

Figure 1. Individual random effects by countries

Source: Author's calculations.

\subsection{Rectification of the Static Relationship of Sustainable Development}

The estimation of the long-term relationship shows that the coefficients of microcredit variables are insignificant since there is a multicollinearity problem between the number of active borrowers (AB) and gross loan portfolio (GLP). There is also a correlation between private and public consumption and the use of telecommunication services (MS). For this, we try to subdivide the model of Heckman and Burton (2017) into four sub-models. From the specification tests, we modeled these four sub-models by a panel with individual effects and we use the two appropriate techniques to estimate the static relationship of sustainable development. Hausman's (1978) arbitration test awarded the nature of the individual random effects for these four relationships. Hence, we applied the GLS procedure to estimate the four sub-models and we relied on the criterion of the significance of microcredit 
variables. The GLS estimates results in Table 6 clearly confirm that the third sub-model is presented as a good specification of sustainable development supported as a function of the portfolio of microcredit service lenders, the percentage of total public expenditure, the GINI inequality index, the user of telecommunication services, the human development indicator and the inflation rate. Except the last variable (INF), all the other variables of this model have expected and significant signs. For this, we must eliminate the number of active borrowers (AB) variable, since it is not significant and it is also correlated with the loan portfolio of microcredit services (GLP). We have also rejected the variable of public and private consumption, since it is correlated with the consumption of telecommunication services (MS) and has proven to be insignificant. Therefore, we have retained the specification of this estimate by the third sub-model according to which microcredit programs have a significant but negative impact on sustainable development.

Table 6. Estimation of the sub-models using GLS regression

\begin{tabular}{|c|c|c|c|c|}
\hline Variables & (1) & (2) & (3) & (4) \\
\hline $\mathrm{LAB}$ & -0.0009246 & -0.0047432 & & \\
\hline LGLP & ---------- & --------- & $-0.0073885^{* *}$ & -0.0020363 \\
\hline LCHE & -0.0244982 & -0.0318958 & $-0.0413603^{* * *}$ & -0.0189915 \\
\hline LGINI & $-0.1014933^{*}$ & $-0.0749298 * *$ & $-0.109503^{*}$ & $-0.0714874 * *$ \\
\hline LMS & $-0.0512166^{*}$ & --------- & $-0.0512359^{*}$ & --------- \\
\hline LHFIC & --------- & $-0.2624524^{*}$ & -------- & $-0.2609276^{*}$ \\
\hline LIDH & $0.5700136^{*}$ & $0.8522606^{*}$ & $0.5483953^{*}$ & $0.8530407 *$ \\
\hline LINF & -0.007379 & 0.0001996 & -0.0087913 & -0.0000426 \\
\hline
\end{tabular}

Note. $* * *, * * *$ denote significance at the $1 \%, 5 \%$ and $10 \%$ levels, respectively.

Source: Author's calculations.

\subsection{Discussion}

Several reasons could be presented to explain this statistically significant and negative impact of microcredit programs on the sustainable development of the MENA region countries. We would like to remind you that the success of such micro-lending programs depends on several micro, meso and macroeconomic conditions. According to these conditions, the targeted clientele of micro loans should be qualified as "poor", the use of micro loans must be productive, the need for outlets to absorb the additional production, the microcredit cost should be lower than the profitability of the activity financed, even more, the dividends and the interest paid by the microcredit institutions do not lead to an external drainage of local revenues towards the shareholders abroad. It is surprisingly exceptional, if not rare, that all the success conditions of such microcredit programs are simultaneously met and that each is perfectly fulfilled in each of the MENA region countries.

Among the conditions for a positive microloans' impact on sustainable development is the cost of the microloan, through the interest rate and fees paid which should be lower than the return on the financed activity. In addressing financial exclusion, one of the challenges for microcredit institutions in MENA countries wanting to reach low-income populations is the relatively high cost of distributing small loans. Although the MENA countries are the least financially integrated in the world, rising international interest rates could directly or indirectly affect its economies. Several MENA countries have traditionally contained inflation by indexing their local currencies to the US dollar, which is a currency with a low inflation rate. Any increase in interest rates by the US Federal Reserve (Fed) could therefore have a direct impact on the economies of MENA countries, since the latter are expected to increase their national interest rates at the same period as the US Federal Reserve (Fed). In MENA countries with fixed exchange rates, such as Saudi Arabia, Oman, Qatar and the United Arab Emirates (UAE), rising U.S. interest rates lead to higher borrowing costs for household's poor and micro enterprises. The financing of investment projects is becoming more expensive, resulting in project delays which largely explain this significantly negative impact of microcredit programs on sustainable development in the MENA countries.

Microcredit could have a positive impact on sustainable economic development when microcredit increases the resources of a so-called "poor" target population. However, in most countries of the MENA region, there has been a growing doubt that poor borrowers are the actual target of these micro loans. This confirms the idea that the demand for microcredit by non-poor populations is due to the fact that financial inclusion is very low in most developing countries (Demirgüç-Kunt \& Klapper, 2012a). For the third consecutive time (2011, 2014, 2017), the Global Findex survey indicated that the Middle East and North Africa countries have the lowest financial inclusion rate in the world (Machado et al., 2018). While the average proportion of people with a bank account in 
developing countries is $63 \%$, it is only $52 \%$ for men and 35\% for women in MENA countries, or 145 million unbanked adults out of 250 million and only $7 \%$ of the population have a mobile money account (Charmes, 2019). All these figures prove that microcredit programs are not playing their full role in terms of financial inclusion of poor borrowers which further explains its negative impact on sustainable development in the MENA region.

One of the conditions for the success of microcredit stipulates that the amount of credit is not sufficient to support micro-entrepreneurship and ensure a positive impact on sustainable development. The success of microcredit also depends on the managerial and technical capacities of the beneficiaries of the microloans. Technical training, financial assistance, managerial support, etc. borrowers are considered as complementary and essential elements for micro loans to be beneficial. These micro-entrepreneurs should acquire the capacity to be better informed about supplies and potential clients. Their living spaces should be opened up, both in rural and urban areas, given the marginalization and abundant exclusions. Hence, the need for the emergence of a new highly technological economy in the MENA region will require a workforce with more solid skills. This lack of competence can be addressed by attracting more women to the tech sector, where they represent only $24 \%$ of the global ICT workforce, according to a report by the World Economic Forum (ILO, 2020). Rising female labor force participation could add \$ 2.7 trillion to the GDP of MENA countries by 2025 (Bonnet et al., 2019).

One of the conditions for the success of microcredit programs is the rapid evolution of technology that promotes financial inclusion. One example is the case of Kenya, where access to M-PESA mobile money services boosted per capita consumption and lifted 194,000 Kenyan households (2\%) out of extreme poverty, with an impact of particularly remarkable income for households that are headed by women (Microfinance Barometer, 2019). This M-PESA institution produces credit scores by taking advantage of mobile phone services. These credit ratings provide banks with enough information to provide micro loans to small borrowers. Since its inception, M-PESA has had 30 million clients and a network of 287,400 agents who are located in around 10 countries. Today, 96\% of households living outside the capital Nairobi each have at least one M-PESA mobile money account (Microfinance Barometer, 2019). In MENA, some elements relating to this technological evolution are already in place. Young people in the Middle East and North Africa (MENA) are already well versed in these digital technologies. These young people are heavy cell phone users and they are very active on social media. The penetration rate of mobile telephony in MENA countries is one of the highest in the world (UNESCO, 2020). However, the disparities between men and women are also significant when it comes to the use and accessibility of mobile telephony.

\section{Conclusion}

On the international scale, the effort to be deployed to achieve Sustainable Development Goals (SDGs) by 2030 is estimated at $\$ 5,000$ billion by the UN (Microfinance Barometer, 2019). This requires that, particularly in the countries of the MENA region, all investors mobilize for the construction of a world which is more based on sustainable development so that the MENA region is more inclusive and more dynamic. Thus, at the micro, meso and macro level, the success of microcredit to constitute an effective economic and financial tool have a positive impact on sustainable development. But in order to fight against poverty, particularly in developing countries, this success depends on a number of conditions. These mainly concern the micro loans' targeted clientele which should be made up of populations qualified as "poor", productive or non-productive use could, in fact, contribute to a positive effect of micro-credit programs on sustainable development. Moreover, the existence of a solvent demand to absorb the productive overcapacity is also supposed to generate a positive impact on sustainable development. A cost of credit should be lower than the rate of return on the activity financed by these granted micro loans. These interests paid to microcredit institutions should not generate an external drain of local resources to foreign countries in the form of paid dividends. However, we have learned that these conditions are simultaneously met and that each is realized in a perfect way far from being realized in the MENA region countries. In a growing number of MENA countries, as the amounts of micro loans increase, the over-indebtedness of these borrowers increases. This is due to the fact that the income generated from the use of these small loans is not sufficient to cover its main financial costs, a large part of which is actually oriented towards consumption. There is also a saturation effect on the demand for credit in certain areas of the MENA region.

However, microcredit in MENA is still a young sector (OECD, 2019). This does not prevent the existence of several successful microfinance practice in MENA such as the Sanadiq project in Jabal al-Hoss (in Syria), the Mu'assasat Bayt Al-Mal (in Lebanon), and in Yemen, the Hodeidah microcredit. There are some reasons why microfinance is not growing remarkably in the MENA region. Referring to the World Bank survey, there are various similar microcredit programs in MENA that differ from the usual microfinance program. The main 
objective of these programs is to reduce the unemployment rate by mobilizing small funds to finance some investment projects. These microfinance programs in some MENA countries have more active borrowers but unfortunately due to the lack of more adequate information system of these programs, the data available is not of good quality.

\section{References}

Archer, G., \& Jones-Christensen, L. (2011). Entrepreneurial value creation through green microfinance: Evidence from Asian microfinance lending criteria. Asian Business \& Management, 10, 331-356. https://doi.org/10.1057/abm.2011.9

Balkenhol, B. (Ed.) (2009). Microfinance et politique publique: Portée, performance et efficience. Paris: Presses universitaires de France. https://doi.org/10.3917/puf.balk.2009.01

Bateman, M. (2012). The Rise and Fall of Microcredit in Post-apartheid South Africa. Le Monde Diplomatique, November 12.

Beck, T., Maimbo, S. M., Faye, I. M., \& Triki, T. (2011). Financing Africa Through the - Crisis and Beyond. The World Bank: Washington, DC. https://doi.org/10.1596/978-0-8213-8797-9

Bonnet, F., Vanek, J., \& Chen, M. (2019). Women and Men in the Informal Economy - A Statistical Brief. Manchester, UK: WIEGO.

Charmes, J. (2019). The Unpaid Care Work and the Labour Market. An analysis of time use data based on the latest World Compilation of Time-use Surveys. International Labour Office - Geneva: ILO.

Convergences Barometers. Microfinance Barometer. (2018). Convergences. Paris, France.

Daley-Harris, S. (2009). State of the Microcredit Summit Campaign Report 2009. Washington, DC. Retrieved from http://www.microcreditsummit.org

Demirgüç-Kunt, A., \& Klapper, L. (2012a). Measuring Financial Inclusion: The Global Findex Database. Policy Research Working Paper, No.6025. The World Bank: Washington, DC. https://doi.org/10.1596/1813-9450-6025

Demirgüç-Kunt, A., \& Klapper, L. (2012b). Financial Inclusion in Africa: An Overview. Policy Research Working Paper, No.6088. The World Bank: Washington, DC. https://doi.org/10.1596/1813-9450-6088

García-Pérez, I., Muñoz-Torres, M. J., \& Fernández-Izquierdo, M. Á. (2017). Microfinance literature: A sustainability level perspective survey. Journal of Cleaner Production, 142(4), 3382-3395. https://doi.org/10.1016/j.jclepro.2016.10.128

García-Pérez, I., Muñoz-Torres, M. J., \& Fernández-Izquierdo, M. Á. (2018). Microfinance institutions fostering sustainable development. Sustainable Development, 26(6), 606-619. https://doi.org/10.1002/sd.1731

Gifford, J. L. (2004). Utilizing, accumulating and protecting livelihood assets: The Role of Urban informal financial services in Kampala, Uganda. In L. Hotze, \& H. Otto (Eds.), Livelihood and Microfinance Anthropological and sociological perspectives on savings and debt. Delft: Eburon.

Heckman, James, J., \& Burton, S. (2017). Abducting Economics. American Economic Review, 107(5), 298-302. https://doi.org/10.1257/aer.p20171118

Hurlin, C., \& Mignon, V. (2006). Une Synthèse des tests de racine unitaire sur données de panel. Economie \& prévision, 169(3), 253-294. https://doi.org/10.3406/ecop.2005.7023

ILO. (2020). Incidence of part-time employment by sex. International Labour Office (ILO), Geneva.

IMF. (2019). Enhancing the Role of SMEs in the Arab World - Some Key Considerations. International Monetary Fund: Washington, DC.

Kar, A. K. (2017). Income Smoothing, Capital Management and Provisioning Behaviour of Microfinance Institutions: A Study Using Global Panel Data. The European Journal of Development Research, 29, 108-126. https://doi.org/10.1057/ejdr.2015.81

Khamar, M. (2020). Global Outreach \& Financial Performance Benchmark Report-2017-2018; Report prepared for MIX. Microfinance Information Exchange: Washington, DC. Retrieved from https://www.themix.org/mixmarket/publications/global-outreach-and-financial-performance-benchmark-rep ort-2017-2018.

Machado, A. C., Bilo, C., Soares, F. V., \& Osorio, R. G. (2018). Overview of Non-contributory Social Protection 
Programmes in the Middle East and North Africa (MENA) Region through a Child and Equity Lens. Brasília and Amman: International Policy Centre for Inclusive Growth and UNICEF Middle East and North Africa Regional Office.

Morduch, J. (1999). The Microfinance Promise. Journal of Economic Literature. 37(4), 1569-1614. https://doi.org/10.1257/jel.37.4.1569

OECD (2020). Women at the core of the fight against COVID-19 crisis. OECD. Retrieved from https://read.oecd-ilibrary. org/view/

OECD. (2019). Enabling Women's Economic Empowerment: New Approaches to Unpaid Care Work in Developing Countries. OECD, Paris. https://doi.org/10.1787/ec90d1b1-en

Ramaswamy, A., \& rishnamoorthy, A. (2016). The Nexus Between Microfinance \& Sustainable Development: Examining The Regulatory Changes Needed For Its Efficient Implementation. European Journal of Sustainable Development, 5(3), 453-460. https://doi.org/10.14207/ejsd.2016.v5n3p453

Roodman, D., \& Qureshi, U. (2008). Microfinance as Business. Working Paper, No.101. Center for Global Development. https://doi.org/10.2139/SSRN.982953

Servet, J. M. (2007). Au-delà du trou noir de la financiarisation. Annuaire suisse de Politique de Développement, 26(2), 25-56. https://doi.org/10.4000/aspd.117

UNESCO. (2020). Covid-19 school closures around the world will hit girls hardest. UNESCO. Retrieved from https://en.unesco.org/news/covid-19-school-closures-around-world-will-hit-girls-hardest

Warnecke, T. (2015). "Greening" Gender Equity: Microfinance and the Sustainable Development Agenda. Journal of Economic Issues, 49(2), 553-562. https://doi.org/10.1080/00213624.2015.1042803

Widiarto, I., Emrouznejad, A., \& Anastasakis, L. (2017). Observing choice of loan methods in not-for-profit microfinance using data envelopment analysis. Expert Systems with Applications, 82, 278-290. https://doi.org/10.1016/j.eswa.2017.03.022

World Bank Group. (2018). The Global Findex Database 2017: Measuring Financial Inclusion and the Fintech Revolution. The World Bank Group: Washington, DC. http://www.worldbank.org/globalfindex

World Bank. (2018). Poverty and Shared Prosperity 2018: Piecing Together the Poverty Puzzle. The World Bank: Washington, DC.

World Bank. (2019), World Development Indicators. The World Bank: Washington, DC. Retrieved from http://data.worldbank.org/data-catalog/world-development-indicators

Zelizer, V. A. (2005). La signification sociale de l'argent. Le Seuil, Paris. https://doi.org/10.4000/lectures.270

Zhang, Q., \& Posso, A. (2017). Microfinance and gender inequality: Cross-country evidence. Applied Economics Letters, 24(20), 1494-1498. https://doi.org/10.1080/13504851.2017.1287851

\section{Notes}

Note 1. http://www.undp.org.ir.

Note 2. World Bank/MENA region/poverty reduction, http://www.worldbank.org.

Note 3. See the presentation in Servet (2007) on the application of this method for the analysis of financial inclusion processes.

Note 4 . With the exception of the variance of innovations which will be assumed to be identical for all individuals.

\section{Copyrights}

Copyright for this article is retained by the author(s), with first publication rights granted to the journal.

This is an open-access article distributed under the terms and conditions of the Creative Commons Attribution license (http://creativecommons.org/licenses/by/4.0/). 